\title{
A silent unheard voice in the Old Testament: The Cushite woman whom Moses married in Numbers 12:1-10
}

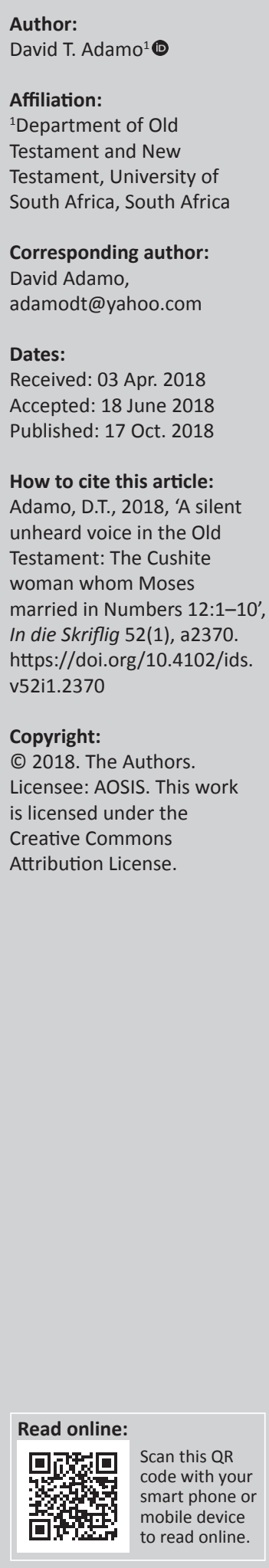

\begin{abstract}
Most of the time, women's names are not mentioned, words are not put in their mouths or they are not allowed to say a word, and their achievements are behind the scene in the narratives. Passages that mention the presence and contribution of African women in the Bible are especially neglected, perhaps because there are few African women biblical scholars and also deep prejudices against women. References to the African wife of Moses (Numbers 12) are so scanty in the Bible that very few critical biblical scholars noticed them. The purpose of this article is to discuss critically the narrative of the Cushite woman whom Moses married and her marginalisation by the author of the story in Numbers 12:1-10. The narrator of the text did not only refuse to give her a name, there is no single word put in her mouth despite the dominant and significant role her presence played in the narrative. Why is she silent and what does her silence mean? The answers to these questions are discussed in this article.
\end{abstract}

\section{Introduction}

The Hebrew Bible and culture is male-oriented in authorship, subject matter, and perspectives (Ebeling 2010:8). This androcentric nature of the Hebrew Bible is clear from the account of the names in the texts. It seems that 'the men who compile these texts are majorly concerned about the world of the male urban elite' (Ebeling 2010:8).

The Bible, like many other Ancient Near Eastern documents, treat women stories as part of someone else's stories (Schneider 2008:10). Most of the silent unheard voices and the unnamed characters in the Bible are women (Brenner 1993:13; Reinhartz 1998:11).

According to Reinhartz (1998:5) there is a general assumption that unnamed characters in the biblical texts are not important and therefore not given prominent attention, thus ignoring or downplaying them. According to Trible (1984:80-81), anonymity is not only a symbol of unimportance but also of a 'lack of power and personhood'. According to Brenner (1993:13), 'the absence of proper name not only effaces narrative identity but also symbolises the suppression of women in Israelite society'. Natanson $(1986: 164,168)$ thinks that despite all the attempts to veil or efface the identity of women by not giving them voices or names by the narrators in the Scripture, their personhood still emerges. The distinctiveness and identities of the unnamed are clear from the specific circumstances that surround them (Reinhartz 1998:4).

The Cushite wife of Moses is one of the minor figures in the book of Numbers, whose stories occupy little scriptural space and receive less attention in the biblical materials. She is one of the women who are on the margin of Israel, mainly as foreigners who came to be included in the story of ancient Israel. Little is known or talked about these women in the Scripture (Hawkins \& Stahlberg 2009:xi). However, Mirriam's stories, unlike the Cushite woman's, occupy a lot of space and attention in the Bible.

The purpose of this article is to examine the biblical narrative of the Cushite woman whom Moses married and her marginalisation by the author or narrator of Numbers 12:1-10. No name and no word were put in her mouth despite the significant role her presence played in the narrative. Many modern scholars do not even recognise her to be an African woman despite that she is referred to as a Cushite, which literally means black. This article will also discuss her identity, reasons for the objection of Miriam and Aaron, and the meaning of her silence in African and semiotic context. 


\section{Various terms used to refer to Africa and Africans in the Old Testament Cush, Cushite and Cushi}

This term is one the most important terms used in the Hebrew Bible to refer to Africa and Africans. Ancient Egyptians seem to refer to black Africans in their southern border as 'Kushu or Kush' (Oswalt 1980:435). They used it to refer to a very limited area of land or tribe beyond Semna and Kerma (Adamo 1986:164, 168), that was later extended to include all the lands further south (Adamo 1986:19; Maspero 1968:488).

According to Lepsius' theory, the Cushites in the land south of Wawat originally came from Asia between the time of Pepi I (2000 вСЕ) and Amenemhat I (1700 вСЕ). They drove back the Africans who occupied the place (Maspero 1968:488 cited Lepsius). Baldwin's theory of the origin of the Cushites as Arabia, before they later settled throughout Africa nearby the Cape of Good Hope, is reasonable (Baldwin n.d.:245). The ancient records of the Egyptians, although sometimes vague, maintain the fact that Cush is located to the south of Egypt. Although there is yet no certainty as to the exact geographical limit of the Kingdom of Cush, 'the brick castle and the great tumuli' uncovered during the excavation at Kerme on the east bank above the Third Cataract, is an evidence that 'the seat of the Kings of Kush' was there and became the place from where the whole 'Kingdom of Kush' was ruled at least from the seventeenth and early sixteenth centuries вСE (Adamo 1986:20; Kemp 1983:71-174).

Ancient Egyptian monuments had evidence that the Egyptian people had several expeditions to the land of Cush as early as the Sixth Dynasty, under Pepi II. Inscriptions of Ameni, Carnarvon Tablet I, the annals of Thutmose III, and the Kuban Stela, the wall of the temple of Redesiay, the stelae of Aezanaa attest to this fact (Breasted 1906:251).

The Assyrian records relating to Africa and Africans refer to Cush or Cusu. Some of them are annalistic texts of Esarhaddon, the Dog River Stele, the Senjirli Stele, the Alabaster Tablets, the Rasam Cylinder of Ashurbanipal and others (Pritchard 1969:232). Perhaps one would be right to say that the term Cush passed from Egypt in Africa to the Assyrians and to the Hebrews.

The term Cush is used in the Old Testament to cover a wide area corresponding to Ethiopia of the classical period. ${ }^{1}$ The term Cush with its generic appears about 57 times in the Old Testament (Oswalt 1980:435; Strong nd:312). Only a summary of its use in the Old Testament will be given.

The Old Testament record is filled with the term Cush and Cushites and they are unmistakably referring to Africa and Africans (Adamo 2005:13-17; Davidson 1977:374). ${ }^{2}$ In terms

\footnotetext{
1.The term Ethiopia literally means 'burnt-face' and is used by the ancient Greeks to refer to the land of Africa and all black people both at home and abroad. It is not limited to present modern Ethiopia.
}

2.Davidson said that the Hebrew term כוש in Arabic means terror, but in the Bible it refers to Ethiopia and its inhabitants. (כושית of a geographical location, it is described as the extreme part of the world (Ezk 29:10; Is 45:14; Job 28:19). The inhabitants of Cush were described as tall and smooth-skinned people. Their blackness becomes proverbial (Is 18:2; Jr 13:23). Moses' wife was from Cush (Nm 12:15). A Cushite man reported the death of Absalom to David (2 Sm 18:21, 31-33). Ebed-Melech was referred to as having a Cushite ancestor (Jr 38:6-14; 39:16-18). The Cushite power was comparable only to the power of the Assyrians. They became the hope of Judah for deliverance from the Assyrians (2 Chr 12:3-9; Is 18:2; $1 \mathrm{Ki}$ 18:19-21; 2 Chr 32:9-15, 3:8).

\section{Egypt or Egyptians}

The term Egypt (Mitrayim) appears more than 740 times in the Old Testament (Adamo 2005:26-36). Cush or Cushite and Egypt or Egyptians were constantly mentioned together in the Old Testament because they both belong to the ancient African nations. This term indisputably refers to Egypt as a country in Africa as well as to the people of ancient Egypt in Africa. Ancient Egypt or the Egyptians were black Africans and not from Europe or Europeans as some have maintained (Adamo 2013b:221-248). The inscriptions of Queen Hatshepsut attested to the fact that Punt is their place of origin. They made several expeditions to Punt (Budge 1976:15-416; Keener \& Usry1996:61; McCray 1990).

Usry and Keener confirm the Africanness and blackness of ancient Egypt and the Egyptians. They maintain that 'most Egyptians were black by any one's definition' (Keener \& Usury 1996:61).

\section{Punt}

Maspero (1968:396) says that 'Punt' lies between the Nile Valley and the Red Sea and is very rich in 'ivory, ebony, gold, metals, gums and sweet-smelling resins'; Budge (1976:512-513) agrees with Maspero. He also emphasised that Punt was the original home of the Egyptian ancestors. Punt was the place where the Egyptians got their minerals, woods, incense and even their hieroglyphic writings. Budge (1976:512-513) also is emphatic that the Egyptians saw themselves as connected with the land of Punt because they belong to the same race and that the relationship between them was very cordial.

Rawlinson (n.d.:72) also agrees with Maspero and Budge. According to him the location of Punt should be sought on the African side of the gulf where the present Somali land is located. He maintains that many Egyptian products and principal gods came from Punt (n.d.:72-75). O'Connor (1982:917-918) says 'Typically, the men have dark reddish skins and fine features; characteristic negroid types ... and the Egyptians have always visited Punt from the time immemorial ...'

\section{Identification of כוֹשית wife of Moses}

An examination of the women in Moses' tradition shows that women have been mentioned prominently and they 
mostly played a role at home and in the celebration of Israel's deliverance (Williams 2002:259-268). The midwives frustrated Pharaoh's plan to kill all the newly born male children of Israel in Egypt (Ex 2). Pharaoh's daughter also saved Moses on the river when his mother could not hide him at home from the authorities and she decided to put him on the river (Ex 2). The courageous sister of Moses, Miriam, kept watching over him. She suggested a nurse to the daughter of Pharaoh, namely his mother to take care of Moses. (Perhaps this were the same Miriam and Aaron who spoke against Moses' authority in Numbers12:1-12, because of the Cushite woman that Moses married).

References to Moses' wives appear only in Exodus 2, 4, 18, and Numbers 12 but do not reappear in any allusion to Moses in the Jewish scriptures. Exodus 2:16, 21 and 3:22 mention the priest of Midian, Ru'el who gave his daughter Zipporah to Moses as a wife and Zipporah bore him a son called Gershom. In Exodus 4:24-26, Zipporah circumcised her son to save the life of her family. She personally spoke herself, 'You are a bridegroom of blood'. Reference to Moses' wives has not reappeared in any other passage except in the Greek translations of the above passages. Jewish writers (Demetrius, Artapanus, and Ezekiel) of the third, and second centuries BCE remembered to mention Moses' wives.

Like other passages where the exact geographical identification of the term Cushite was not given by the Hebrew writers, scholars have spent much energy trying to identify the Cushite woman Moses married. Many scholars identified her with Zipporah, the Midianite (Ex 21:7; Plant 1979:116-117; Winslow 2004:61-73). According to Demetrius, the Chronographer and Ezekiel, the Tragedian, the Cushite wife of Moses in Numbers 12:1-16 is Zipporah (Winslow 2004:61-73). Ibnu-Ezra and Augustine (Bugner 1976:13) are the early scholars who did this. Owen (1970:118-119) compares the Cushite in Numbers 12:1 with 'Cushan' in Habakkuk 3:7 which he identifies with Midian and concluded through parallelism that the Cushite woman in Numbers 12:1 must be Zipporah. Binns also identifies the Cushite woman with Zipporah. He (Binns 1952:75-76) said probably Miriam was jealous because when Zipporah was away to Midian there was no challenge, but when she returned, Miriam's prestige diminished. This appears to have no basis whatsoever. Even though Marsh (1952:200-201) admits the difficulty involved with the identification of the Cushite woman with Zipporah, he is emphatic that the Cushite woman cannot refer to an African, but Zipporah. Martin Noth denies that the Cushite woman refers to an African or the Midianite because Egypt is far removed from Moses' sphere of activity and that the woman belongs to the confederacy of tribes parallel to Midian (Noth 1975:94). However, what the name of the tribe or confederacy is, he does not say. G.B. Gray (1910:121-122) does not even attempt to identify the Cushite woman because he thinks that the verse is an editorial insertion. What is shown above is the evidence of de-Africanisation of the Cushite woman by most Euro-American biblical scholars.
A close examination of this passage (Nm 12:1-16) and other related passages which mention the Cushit, Miriam and Midian show that the Cushite woman cannot be Zipporah, but an African woman, for the following reasons:

- There is no evidence of association of the Cushite woman with Zipporah or a Midianite in the passage or other passages related to Moses' wife, therefore such should not be assumed.

- Midian and Zipporah were never referred to as Kush or Cushite in all the biblical records. Midian and Kush or Midianite and Cushite were never used interchangeably in either the biblical, the Egyptian, or the Assyrian records. Jethro was never called a Cushite. Josephus differentiated between Midian and Kush (Book II:10-1).

- It does not make sense for Miriam to speak against Moses because of a wife (Zipporah) whom Moses had married for about 40 years.

- The Hebrew clause, לקָָ ('because of the Cushite woman which he married' (literally took), 'for he had married a Cushite woman') strongly implies a recent marriage. Therefore, the Jewish tradition of equating the Cushite woman with Zipporah has no basis. It was probably an apologetic device to keep Moses a monogamist (Gray 1910:121-122; Noth 1975:77).

There are four reasons to believe that the Cushite wife of Moses is a black African woman.

Firstly, the article author has personally spent years studying references to Cush, Egyptians and Assyrian in the Old Testament, consulting Egyptian and Assyrian documents and can say with all certainty that in every reference in the biblical, Egyptian and Assyrian records where the word 'Kash', 'Kush', or 'Kushu', are used with a clear geographical or personal identification, it always refers to Africa (Adamo 1986; 2001; 2013a:409; 2013b:4-20; 2013c; 2014; 2018:1-9). An Egyptian inscription as early as the Sixth Dynasty, under Pepi II has the earliest reference to 'Kush'. This monument, the inscription of Ameni, tells us that the king travelled south, overthrew his enemies, 'the abominable Kash, and obtained tributes, past the boundary of Kush, to the end of the earth' (Breasted 1906:251). King Ahmose, who reigned just before the Eighteenth Dynasty, says in the Carnarvon Tablet I:

Let me understand what this strength of mine is for! (One) Prince is in Avaris, another is in Ethiopia (Kus), and (here) I sit associated with an Asiatic and a Negro (Nehesi)! Each man has his slice of this Egypt, dividing up the land with me. I cannot pass by him as far as Memphis. (Pritchard 1969:232)

Another Egyptian monument relating to Kush is the annals of Thutmose III at Karnack, which had three lists of the Cushite cities under his domain. These three lists contain 17, 15 and 400 names respectively. Assyrian documents referred to Africa and Africans as 'Kush' or 'Kusu'. The annalistic texts of Esarhaddon say:

In my tenth campaign I directed my march I ordered ...) toward the country which is Nubia (Kusu) and Egypt (Musur) ... In my campaign, I threw up earthwork (for as against Ba'lu, king of 
Tyre who had put his friend Tirhakah (Tarqu), king of Nubia (against called ... course of siege) trust upon $(K u s u)$.... (Pritcard 1969:292)

The Rasam Cylinder of Ashurbanipal, found in the ruins of Kuyunjik, also referred to Tirhakah as the king of Kusu and Egypt (Luckenbill 1968:294). 2 Chronicles 12:2-3 mentions Shishak who invaded Judah with twelve hundred chariots and 60000 horsemen as the king of Egypt. Among his military men were Cushites, Egyptian and Sukkim. 2 Kings 19:9 mentions King Tirhakah as the king of Cush. As far as scholars and ancient records are concerned, Tirhakah is unquestionably from Africa.

Secondly, the Rabbinical interpretation of the Cushite woman is 'beautiful'. This was based on the proverbial beauty of the Ethiopians (Gray 1910:121).

Thirdly, the Tarqum of Jonathan associated the Cushite wife of Moses in Numbers 12:1 with the queen of Ethiopia:

And Miriam and Aharon spake against Mosheh words that were not becoming with respect to the Kushaitha whom the Kushace has caused Musheh to take when he fled from Pharaoh but whom he had sent away because they had given him the queen of Kush, and he had sent her away. (JERUSALEM). And Miriam and Aharon spake against Mosheh about the Kushaitha whom he had taken. But observe, the Cushite wife was not Zipporah, the wife of Mosheh, but a certain Kushaitha, of a flesh different from every creature. (Etheridge 1968:367-377)

Fourthly, there is a strong tradition which says that Moses married an Ethiopian woman and this Ethiopian was associated with Ethiopia, south of Egypt whose capital was Meroe (Saba). It says that when the Ethiopians oppressed the Egyptians, the Egyptians pleaded with Moses to lead their army against the Ethiopians. Moses agreed, and he became the Egyptian general. When Moses and the Egyptian army besieged the capital city of the Ethiopians, Meroe (Saba), the daughter of the king of Ethiopia, Tharbis, fell in love with Moses. She asked Moses to marry her. Moses agreed on the condition that she delivered the Ethiopians into his hand. Tharbis did so, and after Moses destroyed the Ethiopians, he married Tharbis (Jos 2:10). Other Jewish traditions concerning the story of Moses' campaign in Ethiopia in the Medieval Jewish texts such as Sepher ha-harshar, Pasrashar Shemoth and the Byzantine Chronicle, Palea Historical, where Moses was described as defending the Ethiopians from a usurper named Balaam after which he married the princess of Ethiopia (Runnals 1983:135-156).

Although no one can be sure of the reliability of these traditions, they should not be dismissed outrightly without looking at the facts. One important fact in the tradition which agrees with the biblical account is that Moses married an African woman (Jos 2:1.1).

In the light of this, it is highly probable that after the death of Moses' wife or after she was divorced, or when she travelled to his country (Midian), Moses needed another helpmate fit for him in his leadership responsibility. The question that arises, is why was it that of all the available women, including Israelites, Moses chose to marry an African? The reason may not only be because Yahweh instructed him, but also because African women were beautiful and were held in high esteem. In Isaiah 18:2, Africans are described as 'tall and smooth'. Herodotus also described Africans as the 'tallest and handsomest men in the whole world' (Herodotus $2: 20 ; 3: 14)$.

Therefore, it is relatively certain that the Cushite woman in Numbers is an African. It is probable that she is a daughter of one of the sympathisers of the children of Israel who left Egypt with the Israelites (Adamo 2012:67-78).

\section{Reasons for Miriam's and Aaron's objection}

At this point, it is important to ask why Miriam and Aaron objected to Moses' marriage with the Cushite woman. Many scholars have suggested several reasons why Miriam and Aaron raised an objection to Moses' marriage to the Cushite woman and leadership authority. Bailey (1991:179), Bellis (1994:103), Felder (1989:135-186) and Wagenaar (2003:77) believe very strongly that the main reason for an objection is not to Moses' marriage, but to his superior leadership and privileges. A close reading of the text leaves no doubt that superior leadership experience cannot be excluded from the main reason why Miriam and Aaron raised an objection to the marriage.

However, beyond the leadership authorities are the privileges that come with such authority. These privileges may include respect, gifts donated to authentic leaders by the people, such as harvest and possibly worship.

Sadlers (2005:36) differs in his opinion. According to him, the main reason for the objection to the Cushite woman was because she was a foreigner from Cush. Although this text raises the question of the status of foreign women in Israelite society, this author finds it difficult to agree with the opinion that Miriam's and Aaron's objection were because the Cushite woman was a foreigner. The fact that Moses had earlier married a foreigner from Midian, Zipporah, and there was also no known recorded objection against the marriage, shows that that cannot be the reason for the objection. Despite that the text specifically repeated the phrase 'because of the Cushite woman whom he had married for he had married a Cushite woman' this does not mean that Miriam and Aaron were criticising Moses because of her foreignness. The assumption of Davies (1995:114-116) that Moses' marriage to the Cushite woman was criticised because it challenged the normative assumptions of who is marriageable, is not tenable.

Yet, I hold very strongly that the reason for Miriam's and Aaron's anger cannot be because the Cushite woman was black, according to Knierim and Coats (2005:180-181), Williams (2002:259-268) and Lokel (2007:93-103). Williams emphasised the reason for the objection of Miriam and 
Aaron as 'racist'. To her, the reason for the objection was because 'she was a black African woman.' According to Williams (2002):

The woman from Cush was offensive to Miriam and Aaron because she was a black African woman. We stress here a black African woman because the Egyptian princess in whose house Moses grew up, was an African woman. ... The issue raised by Aaron, Miriam and also the narrator of this story at this point is not that of being anti-foreign, but anti-black. It is a racist issue. This was not only the attitude of Miriam and Aaron. It was the attitude of the narrator also ... This clearly underlines the fact that the Cushiteness of this woman was definitely an issue which the narrator could understand and which the narrator expected his readers to understand. (p. 265)

The above statement cannot be true because there is no prejudice against black people throughout the scriptures. Unlike the situation today when blacks and other racial groups are openly discriminated against and oppressed, black people were highly respected in the ancient time. What I am trying to say, is that prejudice against black people is a modern conception. The modern prejudice has affected their scriptural interpretation. It has been demonstrated over and over that the biblical people have the greatest respect for Africa and Africans (Adamo 1986; 2014:500-530; 2018:1-9).

The prophet Isaiah was very familiar with Africans and their land. In Isaiah 18:1-2 he described them as swift messengers and smooth-skinned people, and people who are feared far and wide:

Ah, land of the whirring wings beyond the rivers of Ethiopia Sending ambassadors by the Nile

Go, you swift messengers, to a people feared near and far, a nation mighty and conquering, whose land the rivers divide (Is 18:1-2 NRSV).

Yahweh used foreign nations (Assyrians, the Babylonians, and the Persians) for punishment, and salvation. He also used Africa and Africans for punishment, salvation and deliverance. It is important that Africa became a place of refuge for ancient Israelites and other nations (Adamo 2018). One will be quite correct to say that real authentic salvation experience for the ancient Israelites started in Africa. In Jeremiah 7:22, 25, 11:24, 16:14, 23:7, 32:21 several allusions were made to bringing Israel's ancestors out of Egyptbondage.

It was not only the prophet Isaiah who recognised Africa and Africans as of great military might, the prophet Jeremiah was emphatic about the Cushite and Egyptian military might (Jr 46:1-12). That happened after the collapse of the Assyrian power and Africa re-asserted her dominion over the SyroPalestinian people and forced Judah into a state of vassalage (Adamo 2018:1-8). In the poem in Jeremiah 46 the Cush and Put were described as gibborim.

Such passages like the above and Isaiah 18, 20, 30:1-2; 31:1, 3 recorded the prophetic struggle to fight ancient Israel's military and political dependence on African nations for deliverance. The prophets Isaiah, Ezekiel, Amos, and Jeremiah would never have spent so much time prophesying so vehemently against these African nations and their military men if ancient Israel had not depended on them. They must have been responsible for the 'extremism and bizarre quality of some of the prophets' actions and speeches against the African nations (Adamo 2018; Bailey 1991:165-184).

The prophet Jeremiah portrayed Africans as people of a high sense of moral judgement (Jr 30:7-10). When king Zedekiah evaded his responsibility and the aggressive nobles threw the prophet Jeremiah into the pit to die, a man of African ancestry called Ebed-Melech, was the only courageous man who challenged king Zedekiah for inappropriate action and then got the prophet Jeremiah delivered (Adamo 2018:6). When scholars examined Ebed-Melech's courage, compassion, dispatch, and ability to bring out the best in king Zedekiah, this story is adjudged to be one of the fairest stories in the Old Testament (Adamo 2018:6; Smith 1929:28). As far as the identity of Ebed-Melech is concerned, the biblical writer identifies him as of African ancestry because his grandparents were traced to Cush (Jr 37:7-13). Africa was used as valuation for ancient Israel (Jr 13:23).

Can Ethiopians change their skin or leopards their spots?

Then also you can do good who are accustomed to do evil. (Jr 13:23 NRSV)

Admittedly, the reading of Jeremiah 13:23 at a glance makes it seem as if the biblical people had the prejudice against the African people, the Cushites. However, when the above verse is translated and interpreted appropriately in an African context, there is nothing like prejudice against black Africa. What I consider to be the appropriate translation is, 'Would black Africans change their skin, or the leopards their spots? So also you who learnt to do evil, could do good'.

I believe that this translation agrees with the prophet Jeremiah's charge that the people of Judah are doers of evil and that black Africans and the leopard have learnt the advantages of who they are, that is, conqueror of territories. So also those who have learnt to sin perpetually, have learnt the advantages of being sinners. According to the prophet Jeremiah, it is unthinkable that black Africans and the leopard will want to change the way they look (Adamo 2014:500-530; 2018:6-7; Bailey 1991:171). The prophet wanted Judah to use black people as a yardstick for assessing themselves. Or that it is very unlikely that black Africans will desire to be white because it is unnatural (Dunston 1974:47). Since black Africans are respected throughout the biblical period and the colour of their skin was never a dispute, I maintain the position that Miriam and Aaron did not object to Moses' marriage because of the blackness of the Cushite.

What I consider to be the main reason for the objection to this marriage, is jealousy. Miriam and Aaron were jealous because Moses had two wives and because more of his attention would have been taken by the newly married woman. It is 
not unusual in an African setting for relatives and friends to be jealous when husbands are too occupied with two or three wives. Perhaps Miriam and Aaron were shocked because Moses did not consult Miriam and Aaron before consummating his marriage to the Cushite woman and then claimed that Yahweh told him to marry her. Perhaps as coprophets, Moses usually consulted Miriam and Aaron before taking such an important prophetic decision, but on this occasion, they were not consulted. As said above, Williams' idea as reason for the objection, is not acceptable. Unlike the situation today when blacks and other racial groups are openly discriminated against and oppressed, black people were highly respected in the ancient times. What I am trying to say, is that prejudice against black people is a modern conception. The modern prejudice has affected their scriptural interpretation. It has been demonstrated times and again that the biblical people have the utmost respect for Africa and Africans (Adamo 1986; 2014:500-530; 2018:1-9).

\section{The meaning of the silence of the Cushite woman}

When one reads the narrative in Numbers 12:1-10 one notices that there are about six main characters in the narrative. These characters are Moses, the Cushite woman, Miriam, Aaron, God and the narrator. At one point, these characters are spoken to, except the Cushite woman. The Cushite woman did not speak to any of the characters and none of these characters spoke to her directly or indirectly. The Cushite woman's silence and the silence of other actors in the narrative about the Cushite woman, make it difficult to identify her or know her contribution to the entire affairs (Williams 2002:263). To make the situation worse, the Scripture spoke about Moses, Miriam, Aaron, and God in other passages, but is silent about the Cushite woman alone. That prompts scholars to ask some basic questions about her. Why did she not utter a word herself? Or why did the narrator not put a word in her mouth? Was she not present when the whole episode took place? Did she deliberately keep silent out of her own volition because she thinks that the family can solve their own problems? Was she keeping quiet because of her inferiority? A more important question is whether her silence communicate some things in the whole discussion. I believe that the Cushite woman was present during the whole incident. As I have already said above, the 'Hebrew

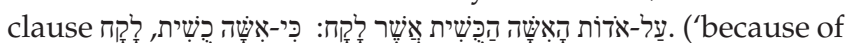
the Cushite woman which he married' (literally took), 'for he had married a Cushite woman'), strongly implies a recent marriage. I do not think that any wise husband will send a newly married wife away. She was silent probably because she was thinking that the family could sort out their problems and therefore have confidence in her husband to defend her. As I have said above, there is no prejudice against black people, therefore she was not feeling any inferiority complex. She did not keep silent because of racism.

The fact is that even though the Cushite woman was silent, her silence was meant to communicate something. To know what her silence means and communicates, it is important to understand how silence conveys a message. In other words, one must be familiar with silence as a cultural element, as well as the conversational functions and value of silence (Adamo 2007:91-98).

\section{Silence as a cultural element}

Because mankind is a social animal, sound and silence are used to constitute part of culture and culture as communication. Since a culture 'is an immensely intricate series of complexes, sound and silence ... are the most important complex in live culture' (Poyatoes 1983:218). In the study of paralinguistic phenomena many kinds of silence have been identified. The first one is what is called 'hesitation phenomena'. This has to do with different utterances such as 'um,' 'ah,' or 'well', and others without saying anything further (Poyates 1983:231). Another kind of silence is what is called 'Psycholinguistic hesitation' (Adamo 2007:92; Bruneau 1979:26). This is related to the encoding a decoding of speech. This helps 'the encoder to process mental thought into the proper words or grammatical forms to be spoken' (Adamo 2007:93). Another type of silence is 'interactive silence' which is always longer than 'psycholinguistic silences' (Adamo 2007:93). Poyatoes also mentions a special category of silence formed by 'interactional pauses', which includes 'absent turn-taking pause, turn-claiming pause, turn-ending pause, transitional pause, task-performing pause, feedback seeking pause and hesitation pause' (Adamo 2007:93; Poyatoes 1983:230).

\section{Function and value of silence}

When silence is viewed semiotically and in an African context, silence has various functions and values. Adamo (2007:95-98) mentions the functions of values, and the meaning of silence.

Among the Yoruba speaking people of Nigeria, silence does not mean stupidity. Silence does not mean that one is not communicating. Silence can mean disapproval. For example, if a wife or a child is asking for permission to travel with her husband and the husband does not answer her, it means disapproval. It means that her husband has communicated disapproval by his silence. Silence can also mean anger or displeasure. In the absent turn-taking silence, that is, when the other partner refuses to take his or her turn and speak, it may mean anger or displeasure. It means that the partner has communicated displeasure or annoyance. Displeasure could be communicated by the refusal to take a turn. Another meaning of silence is indifference. This can mean indifference toward the issue being discussed. Silence may communicate malice, contempt or jealousy. Most of the time silence may communicate these when there is a previous quarrel. It may be used to be 'a marker of being agreeable in some pragmatic situations' (Adamo 2007:97). In this situation, it is always accompanied with a nod of a head or smile. Silence may mean sorrow. This usually happens in a situation of mourning and is sometimes accompanied by sobbing. Silence can be used to communicate confusion. For example, if a 
co-interactant is silent, so unexpectedly it could be because of confusion.

In the light of the above, one can say that the culture of silence in Africa (Yoruba) is probably close to that of ancient Israel, especially when it pertains to the marginalisation of women and when they are to keep their silence when authorities are arguing.

One of the underlying reasons for the objection to Moses' authority is not only that of Miriam' jealousy, but also overprotection of Miriam over her brother whom she spent so much time and risk for. This may be true if one remembers the account in Exodus 2:1-10. Moses was born in dangerous circumstances, that is, at the time when there was a decree that all male children should be murdered. Three months after Moses was born, Moses' parents could not hide him anymore. His sister, Miriam, agreed to watch over him when he was put in the basket by the river so that nothing would happen to him. One will be right to assume that Miriam was the same sister of Moses in Exodus 2, because there was no tradition that this sister of Moses was someone else other than Miriam. If at the tender age, she was courageously protective and using her intelligence to confront the prestigious daughter of Pharaoh with a brilliant plan to save her brother, it will be accurate to believe that at a grown-up age, she continued to be jealous and protective of her brother, Moses. ${ }^{3}$ She must be jealous not because the Cushit was black, but because her brother would not pay enough attention to her with two wives. Moreover, she might desire that the prophetic duty should be consultative among her, her brother, and Aaron.

In the light of the above semiotic meaning of silence in the African context, it suggests that the meaning of the Cushit's silence can be possible the following:

- The Cushit woman was silent because she was aware that the argument was simply a result of jealousy by Miriam and Aaron. There is no need for her to utter a word.

- The black African woman was silent because she believed that God would fight for her and vindicate her; for an African woman in a polygamous house will normally say: 'Fi ija fun Olorun ja fowo leran' (leave the fight for God and watch calmly) whenever there was terrible jealousy beyond what she could handle.

- She may be silent because she believed that her husband would defend her.

- The black African woman might be silent as a sign of contempt against, not her husband, but Miriam and Aaron, as silence in African culture and tradition could mean.

- The black African woman may be silent to convey a sign of sorrow, anger and disapproval of Miriam and Aaron's objection to Moses' marriage to her.

- The black African woman might be silent to convey indifference to what was being discussed.

3.In the light of her previous courageous and aggressive action, Miriam might have been bullying Moses in the presence of the Cushit woman; and because of he aggression and shouting, the Cushit remain silent and was afraid to say anything.

\section{Conclusion}

I have discussed the fact that the Cushite wife of Moses was a black African woman from Cush or Africa. I have also objected to the fact that the reason for the objection of Miriam and Aaron was not because she was black, or that she was from a black country, Cush. The main reason for this position is that the author of this article is aware, through several types of research on the subject, that there has been no prejudice against black colour or black people in the Old Testament. The interpreters, mostly Western exegetes, were the ones who brought modern prejudice to the interpretation of the Bible. What appears to me to be the reasons for the objection, is jealousy of Moses' authority and the privileges accorded to this authority. The over-protective spirit of Miriam cannot be left out of this objection.

The African wife of Moses was silent not because she was a coward or inferior, but her silence was meant to convey some messages. These messages include indifference on her part, sorrow, anger and disapproval of Miriam and Aaron's protest.

Although the Old Testament culture relegates women or wives to the background, one will be correct to say that this Cushite woman must have contributed to the achievement of Moses as a law-giver, as prophet and as a deliverer, if we apply the saying that 'Behind any great man, there is a woman'. It is gratifying that one of the greatest leaders of ancient Israel has an African wife.

This has some implication to the church in Africa. It means that Africa and Africans participated in the drama of redemption. It means that the Christian canon, the Bible, is not a foreign book as such as the anti-colonial agitators have maintained. It relieves the black church and black Christians from the inferiority complex imposed on Africa and Africans by the Euro-American slave masters, who believe that Africans are less than human beings.

\section{Acknowledgements Competing interests}

The author declares that he has no financial or personal relationships which may have inappropriately influenced him in writing this article.

\section{References}

Adamo, D.T., 1986, 'Africa and Africans in the Old Testament and its environment', PhD Dissertation, Baylor University, Waco, TX.

Adamo, D.T., 2001, Africa and the Africans in the Old Testament, Wipf \& Stock, Eugene, OR.

Adamo, D.T, 2005, Africa and the Africans in the Old Testament, Justice Jeco, Benin.

Adamo, G., 2007, 'Silence as a message conveying process: A study of Yoruba speakers of English in Nigeria', International Journal of Communication 17(1), 91-99.

Adamo, D.T., 2012, 'A mixed multitude: An African reading of Exodus12:38', in G. Brenner (ed.), Exodus and Deuteronomy, pp. 67-78, Fortress, Minneapolis, MN.

Adamo, D.T., 2013a, 'The African wife of Joseph, Asenath', Journal of Semitics 22(2), 409-425.

Adamo, D.T., 2013b, 'The nameless African wife of Potiphar and her contribution to ancient Israel', Old Testament Essay 23(2), 221-248. 
Adamo, D.T., 2013c, 'The African wife of Jeroboam', Theologia Viatorum 37(), 71-89.

Adamo D.T., 2014, 'The portrayal of Africa and Africans in the pentateuch and the major prophets: Implication for Christianity in modern Africa,' Theologia Viatorum 38(1), 63-77.

Adamo, D.T., 2018, 'The portrayer of Africa and Africans in the book of Jeremiah', In die Skriflig 52(1), a2259. https://doi.org/10.4102/ids.v52i1.2259

Bailey, R., 1991, 'Beyond identification: The use of Africans in the Old Testament poetry and narratives,' in C. Felder (ed.), Stony the road we trod: African American interpretation, pp. 165-184, Fortress, Minneapolis, MN.

Bellis, A.O., 1994, Helpmates, heroes: Women's stories in Hebrew Bible, Westminster Louisville, KY.

Binns, E., 1952, The book of Numbers, Methuen, London

Breasted, J., 1906, Ancient records of Egypt, vol. I, University of Chicago Press, Chicago, IL.

Brenner, A., 1993, Introduction: A feminist companion to judges, Sheffield Academic Press, Sheffield.

Bruneau, T., 1979, 'Communication silences: Forms and functions', The Journal of Communication 23, 117-146.

Budge, C., 1976, The Egyptian Sudan, vol. 1, Arno Press, New York.

Bugner, L., 1976, The image of the black in western art, William Morrow, New York.

Davidson, B., 1977, שוכ Analytical Hebrew and Chaldee Lexicon, Zondervan, Grand Rapids, MI.

Davies, E., 1995, Numbers: The road to freedom, Sheffield Phonix Press, Sheffield. (Phoenix Guide to the Old Testament).

Dunston, A, 1974, The black man in the Old Testament and its world, Dorrance, Philadelphia.

Ebeling, J.R., 2010, Women's lives in the biblical times, Clark, New York.

Etheridge, J.W., 1968, The targums of Onkelos and Jonathan Ben Uzziel on the pentateuch, KTAV Publication House, New York.

Felder, C.H., 1989, Troubling biblical waters: Race, class and family, Orbis, New York.

Gray, G.B., 1910, A critical and exegetical commentary on the book of Numbers, Charles Scribner, New York. (The International Critical Commentary).

Hawkins, S. \& Stahlberg, L. (eds.), 2009, From the margins 1: Women of the Hebrew Bible and their afterlives, Sheffield Phoenix, Sheffield.

Herodotus, II, 2:137-140; 2:152-154.

Keener, C. \& Usry, G., 1996, Black man's religion, Intervarsity Press, Downer's Grove.

Kemp, B.J, 1983, 'Old Kingdom, Middle Kingdom, and Second Intermediate Period 2686-1522', In B.G Trigger, B.J Kemp, D. O'Connor \& A.B Lloyd (eds.) Ancient Egypt: A social history, pp. 71-174, Cambridge University Press, Cambridge.

Knierim, P. \& Coats, G., 2005, Numbers, Eerdmans, Grand Rapids, MI.
Lokel, P., 2007, 'Moses and his Cushite wife reading Numbers 12:1 with undergraduate student of Makerere University', in K. Holter (ed.), Interpreting classical religious texts, pp. 93-103, Acton Publishers, Nairobi.

Luckenbill, D., 1968, Ancient records of Assyria and Babylonia, vol. 2, Greenwood, New York.

Maspero, G., 1968, The dawn of civilization, vols. 1 \& 2, transl. M.L. McClure, Frederick Ungar Publication, New York.

Natanson, M., 1986, Anonymity: A study of the philosophy of Alfred Schutz, Indiana University Press, Bloomington, IN.

Noth, M., 1960, A history of Israel, transl. P.R. Ackrod (rev. eng. transl.), Harper, New York.

Noth, M., 1975, Numbers: A commentary, transl. J.D. Martin, SCM, London.

O'Connor, D., 1982, 'Egypt 1552-664 bc', in J.D. Cleric (ed.), Cambridge History of Africa, pp. 917-918, Cambridge University Press, Cambridge.

Oswalt, J.N., 1980, כוש in Theological Wordbook of the Old Testament, 2, R.L Harris, G.L Archer Jr \& B.K. Waltke (eds.), p. 435, Moody Press, Chicago, IL.

Owen, J.J., 1970, Leviticus, Ruth: The Broadman Bible Commentary, vol. 2, Broadman Press, Nashville, KY.

Plant, G.P., 1979, Numbers, The Torah: A modern commentary, vol. 4, Union of American Hebrew Congregations, New York.

Poyates, F., 1983, New perspective in nonverbal communication', Pergamon, New York.

Pritchard, J. (ed.), 1969, Ancient near Eastern text relating to the Old Testament, Princeton University Press, Princeton, NJ.

Rawlinson, G., n.d., History of ancient Egypt, vols. 1 \& 2, Clarke, Chicago, IL.

Reinhartz, A., 1998, 'Why ask my name?: Anonymity and identity in biblical narrative', Oxford University Press, New York.

Runnals, D., 1983, 'Moses'Ethiopian campaign', Journal of the Study of Judaism in the Persian 14, 140-142.

Sadlers, R.S., 2005, 'Can a Cushite change his skin? An examination of race, ethnicity and othering in the Hebrew Bible, Clark, New York.

Schneider, T., 2008, Mothers of promise, Baker Book House, Grand Rapids, MI.

Smith, N., 1929, Jeremiah, 4th edn., Harper \& Row, New York.

Strong, J., n.d., Ethiopia, Dugan, Gordonsville, VA. (Strong's exhaustive concordance of the Bible).

Trible, P., 1984, Text of terror: Literary feminist readings of biblical narrative, Fortress, Philadelphia, PA.

Wagenaar, H., 2003, 'White as snow: Numbers 12 from an African perspective', Africa Theological Journal 1(26), 75-87.

Williams, J., 2002, 'And she became Snow White: Numbers 12:1-16', Old Testament Essays 15(2), 259-268.

Winslow, K., 2004, Proceedings Eerdmans, Grand Rapids, MI. 